University of Maryland Francis King Carey School of Law

DigitalCommons@UM Carey Law

\title{
Library Services for the Self-Interested Law School: Enhancing the Visibility of Faculty Scholarship
}

\author{
Simon Canick \\ University of Maryland Francis King Carey School of Law, scanick@law.umaryland.edu
}

Follow this and additional works at: https://digitalcommons.law.umaryland.edu/fac_pubs

Part of the Legal Education Commons, and the Legal Writing and Research Commons

\section{Digital Commons Citation}

Canick, Simon, "Library Services for the Self-Interested Law School: Enhancing the Visibility of Faculty Scholarship" (2013). Faculty Scholarship. 1568.

https://digitalcommons.law.umaryland.edu/fac_pubs/1568

This Article is brought to you for free and open access by the Francis King Carey School of Law Faculty at DigitalCommons@UM Carey Law. It has been accepted for inclusion in Faculty Scholarship by an authorized administrator of DigitalCommons@UM Carey Law. For more information, please contact smccarty@law.umaryland.edu. 


\title{
Library Services for the Self-Interested Law School: Enhancing the Visibility of Faculty Scholarship ${ }^{\star}$
}

\author{
Simon Canick
}

This article suggests a new set of filters through which to evaluate law library services, in particular those that support faculty scholarship. These filters include recent profound changes in legal education and the motivators of today's law professors. By understanding the needs of self-interested deans and professors, libraries can fill new roles that are consistent with our core values. Libraries can also focus on dissemination and promotion of faculty work, especially through innovative open access projects.

Introduction: Library Services in a Period of Transition . . . . . . . . . . 175

The New Normal in Legal Education . . . . . . . . . . . . . . . . . . . 176

What Do Deans and Professors Want from the Library? . . . . . . . . . . . . 179

Motivation: Why Law Professors Teach, Write, and Serve . . . . . . . . . . . 180

Support for Production and Visibility of Faculty Scholarship . . . . . . . . . . . . 184

Moving Forward with Open Access: E-book Initiatives . . . . . . . . . . . . . 191

Practice Guides and Treatises ........................... 192

Casebooks ... . . . . . . . . . . . . . . . . . . . . . . . . . . . . . . . . . . . . 194

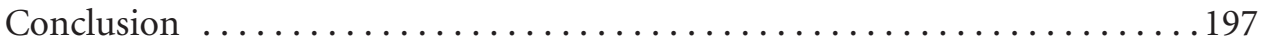

Appendix: Faculty Scholarship on SSRN and Mitchell Open Access. . . . . . . . 198

\section{Introduction: Library Services in a Period of Transition}

I1 Every so often, especially after a particularly painful round of budget cutting, academic law librarians start wringing their hands, saying: "Cutting staff in the library is short-sighted!" "Why don't they understand how important we are?" or "We have to do a better job articulating the value we add to the school!" Underlying these comments is the notion that if law school administrators understood the library, things would be different. This reaction is predictably consistent with human nature; after all, we work hard, we help people, we care, we are smart, we do important work. It is easier to believe that those making decisions are shortsighted or incompetent than to accept steep cuts as a negative judgment. A more productive approach for librarians is to recognize that while others in the law school probably do have a pretty good idea of what we do, they just may not value

* (C) Simon Canick, 2013.

** Associate Dean for Information Resources and Associate Professor of Law, William Mitchell College of Law, St. Paul, Minnesota. 
the library's contribution as highly as we do. Further, we might concede that law school administrators who also have an eye on other departments are better suited than most librarians to judge the relative value of our services.

I2 Librarians' evaluation of the administration's wisdom in these matters may be predictive of how we fare the next time the school looks for budget savings. Feeling misunderstood or underappreciated leads to a defensive posture, and consequently diminishes our credibility. It may also result in our exclusion from future conversations and in steep library cuts without meaningful librarian input. Instead, librarians should listen carefully and ask questions designed to assess the school's priorities. There should be nothing to defend: our goal is deeper understanding, creative thinking, and innovation, not a particular outcome.

I3 Unsurprisingly, budget-related conversations are often challenging and emotionally charged. Readers might imagine a room full of senior administrators, each of whom brings a particular perspective based on their own work. All of that work is certainly important. With demand for legal education declining, we need terrific admissions and marketing officers to recruit prospective students. In a tough job market, we need outstanding career services staff with solid connections. As tuition revenue declines, we need accomplished fund-raisers. Meanwhile professors remain the core of the educational program, and besides, most have tenure. This scenario has implications for everyone who works in the library. A director needs to see past his own staff and recognize the value that others bring, generate an accurate view of where the library fits, and envision ways to support evolving strategic priorities. Library staff members need to help their director to think of new services that support those priorities.

\section{The New Normal in Legal Education}

I4 Legal education has entered a period of profound change and reflection. In just two years, the number of LSAT test takers is down by twenty-four percent, ${ }^{1}$ and law school applicants have dropped by twenty-three percent. ${ }^{2}$ The job market is

1. LSATS Administered, LAW SCH. ADMISSION COUNCIL, http://www.lsac.org/lsacresources/data /lsats-administered.asp (last visited Jan. 26, 2013). The October 2012 test administration showed a $16.4 \%$ year-over-year decline in test takers, after a $16.9 \%$ drop the year before. $I d$.

2. LSAC Volume Summary, LAW SCH. ADMISSION COUNCIL, http://www.lsac.org/lsacresources /data/lsac-volume-summary.asp (last visited Jan. 26, 2013). See also Matt Leichter, A Tale of Two (California) Law Schools, AM. LAW DAILY (Sept. 7, 2012), http://www.americanlawyer.com /PubArticleALD.jsp?id=1202570535871 (reporting an 18\% drop from 2011 to 2012 in the number of applicants with LSAT scores of 160 or higher). 
poor. ${ }^{3}$ Media outlets, including the New York Times, ${ }^{4}$ Wall Street Journal, ${ }^{5}$ and NPR, ${ }^{6}$ have all publicized the downturn, and their message to prospective students has been clear: law school is at best a risky investment and at worst an outright scam. Deans, professors, the ABA, and economists have all weighed in. Some believe the downturn is cyclical; if we ride out the storm the market will recover. ${ }^{7}$ Others anticipate a complete transformation in the way law schools operate, from pedagogy ${ }^{8}$ to transparency in reporting information, ${ }^{9}$ technology, ${ }^{10}$ and tenure and security of position. ${ }^{11}$

\$5 Law schools face a fundamental business decision: accept fewer students with similar credentials, lower the qualifications to entry in order to boost enrollment, or some combination of the two. ${ }^{12}$ Many schools will seek short- or mediumterm budget cuts, and others will restructure their operations. Many others will lay

3. Joe Palazzolo, Law Grads Face Brutal Job Market, WALL ST. J., June 25, 2012, at A1 (reporting that nine months after graduation, "[j] ust a dozen schools reported that $80 \%$ or more of graduates found full-time, long-term legal jobs.").

4. In 2011, the New York Times ran a series of five long, provocative, and harshly critical reports on the state of legal education: David Segal, Is Law School a Losing Game?, N.Y. TIMES, Jan. 9, 2011, at BU1; David Segal, Behind the Curve: How Law Students Lose the Grant Game, and How Their Schools Win, N.Y. Times, May 1, 2011, at BU1; David Segal, Law School Economics: Ka-Ching!, N.Y. TimEs, July 17, 2011, at BU1; David Segal, What They Don't Teach Law Students: Lawyering, N.Y. TimES, Nov. 20, 2011, at A1; David Segal, The Price to Play Its Way: How the A.B.A.'s Rules Are Helping to Raise Law School Tuition, N.Y. Times, Dec. 18, 2011, at BU1. See also Editorial, Legal Education Reform, N.Y. Times, Nov. 26, 2011, at A18.

5. Carl Bialik, Job Prospects for Law Grads? The Jury's Out, WALL ST. J., Mar. 17, 2012, at A2.

6. Larry Abramson, Do Law Schools Cook Their Employment Numbers?, NPR, Jan. 16, 2012, http://www.npr.org/2012/01/16/145179563/do-law-schools-cook-their-employment-numbers.

7. See, e.g., Lawrence E. Mitchell, Law School Is Worth the Money, N.Y. TimeS, Nov. 29, 2012, at A31; Aaron N. Taylor, Commentary, Why Law School Is Still Worth It, NAT'L JuRIST Prelaw (Oct. 11, 2011), http://www.nationaljurist.com/content/why-law-school-still-worth-it (noting signs that the legal job market is thawing).

8. See Press Release, Kaplan Test Prep Survey: Facing a Tough Employment Landscape for New Lawyers, Law Schools Cut the Size of Their Entering Classes and Revise Curriculum to Adapt to Evolving Market (Nov. 19, 2012), http://press.kaptest.com/press-releases/kaplan-test-prep-survey -facing-a-tough-employment-landscape-for-new-lawyers-law-schools-cut-the-size-of-their-entering -classes-and-revise-curriculum-to-adapt-to-evolving-market. See also R. Michael Cassidy, Beyond Practical Skills: Nine Steps for Improving Legal Education Now, 53 B.C. L. Rev. 1515 (2012).

9. See Transparency Index, LaW SCH. TRANSPARENCY, http://www.lawschooltransparency.com /reform/projects/Transparency-Index/ (last visited Jan. 26, 2013).

10. Jon M. Garon, Legal Education in Disruption: The Headwinds and Tailwinds of Technology 56-57 (Apr. 15, 2012), http://ssrn.com/abstract=2040560.

11. Karen Sloan, "Voldemort" Attempts to Salve Worries That ABA Might Drop Tenure Requirement, NAT'L L.J. (ONLINE) (Jan. 7, 2001) (available only on LexisNexis) (noting that New York Law School dean Richard Matasar suggested that "the proposal would open the door for new law schools to have the flexibility to take a different approach to staffing and develop lower-cost ways to deliver legal education," and "faculty salary represents between $45 \%$ and $50 \%$ of law school budgets.").

12. See, e.g., Paul L. Caron, Carnage in $1 L$ Law School Enrollments, TAxProf Blog (Sept. 22, 2012), http://taxprof.typepad.com/taxprof_blog/2012/09/carnage-.html (finding that thirty-one law schools had more than a ten percent drop in first-year enrollment in fall 2012); Beth Hawkins, To Cope with Changing Market, Hamline Retools with Law School 2.0, MinnPost (June 11, 2012), http:// www.minnpost.com/learning-curve/2012/06/cope-changing-market-hamline-retools-law-school-20 (noting Hamline Law School's plan to cut J.D. enrollment while emphasizing technology-based, non-J.D. certificate programs); Karen Sloan, Hastings College Cutbacks a Response to Legal Education's "Crisis," NAT'L L.J. (ONLINE) (Apr. 30, 2012) (available only on LexisNexis) (reporting the University of California Hastings College of Law's three-year goal of trimming enrollment by twenty percent). 
off staff and institute pay or benefit cuts. ${ }^{13}$ A few law schools are likely to close down, while others may merge. ${ }^{14}$

I6 Now think again about the relative value of library services. Most academic law libraries were designed to store books that nowadays are rarely used, yet our budgets remain skewed toward the purchase, processing, and organization of print materials. Even as disintermediation has cut traffic at the reference desk, we have added reference positions and services. ${ }^{15}$ As services proliferate, more librarians are hired to provide them. But our evolution lacks the harsh reality of natural selection-as long as staffing levels increase over time, there is little incentive to cull less critical services. ${ }^{16}$ Our instructional role is extensive, but its impact and relative strategic value are unclear. ${ }^{17}$ We write guides and tutorials but know little about

13. The Hastings strategic plan included "[1]ayoffs, reductions in time, voluntary separations, and closing of vacant positions." Frank H. Wu, Spring 2012 Strategic Plan Implementation Update, Univ. of Cal. Hastings College of The Law (Apr. 19, 2012), http://www.uchastings.edu/about /leadership/chancellor-dean/letters/04-19-12a.php. Four members of the library staff were laid off, and two others had their hours reduced. See Final Reorganization List, Univ. of Calif. Hastings Coll. of Law (on file with author; document was removed from law school's web site); see also Matt Bodie, Reforming Legal Education's Finances: How to Cut Salaries, PrawfsBlawg (Nov. 15, 2012), http:// prawfsblawg.blogs.com/prawfsblawg/2012/11/reforming-legal-educations-finances-how-to-cut -salaries.html (focusing on cutting faculty salaries as an alternative to layoffs).

14. See Brian Leiter, Predictions About Closings of ABA-Accredited Law Schools over the Next Decade, BRIAN LEITER'S LAW SCH. REPORTS (Oct. 3, 2012), http://leiterlawschool.typepad.com /leiter/2012/10/predictions-about-closings-of-aba-accredited-law-schools-over-the-next-decade .html (predicting that at least a few law schools will close).

15. From 1993 to 2011, median FTE professional librarian positions have increased from 7.5 to 8.4. Am. Bar Ass'n, Sect. on Legal Education \& Admissions to the Bar, Comprehensive Law Library Statistical Table_-Data from Fall 1993 Annual Questionnaire (May 12, 1994); Am. Bar Ass'n, Sect. on Legal Education \& Admissions to the Bar, Comprehensive Law Library Statistical Table-Data from Fall 2011 Annual Questionnaire (Apr. 10, 2012) (both on file with author).

16. But see Carl Yirka, The Yirka Question and Yirka's Answer: What Should Law Libraries Stop Doing in Order to Address Higher Priority Initiatives?, AALL SPECTRUM, July 2008, at 28.

17. Teaching legal research can be a strategic decision by the library, but probably only to the extent that teaching it a certain way helps the school balance its budget. Having librarians teach the research component of the first-year program may mean hiring fewer adjuncts, or could free up time for the full-time faculty. If the priority is cost-cutting, will the dean care that moving research instruction to the first year may mean losing several advanced research classes with low enrollment?

This analysis can be applied to other areas as well. Library functions frequently overlap with those of other law school departments. For example, both library staff and administrative assistants gather materials for professors and upload documents to course management sites. If the school has an open position for a faculty support administrative assistant, the library might offer to take responsibility for the overlapping functions. That could be enough for the school to redefine the support role as part time, and save salary and benefit dollars. Meanwhile, the service will improve because library workers can search and retrieve information more efficiently. As an added benefit, centralizing support for course management is a strategic service tied to innovation in teaching with technology, faculty-student communication, and the transition to electronic textbooks. Another option is to embrace the research assistant (RA) pool model, under which the library budgets for and coordinates the activities of RAs. This approach serves professors whose research needs fluctuate and provides a higher level of training and oversight for students, who benefit from working with numerous professors with varied research interests. See, e.g., Darcy Kirk \& Barbara Rainwater, The Research Assistant Pool in the Law Library, 6 Trends L. Libr. Mgmt. \& TeCH. 4 (1994-1995). If comprehensive oversight of law school RAs is not possible, consider an arrangement with the law school administration whereby RAs from the library's pool do not count against professors' discretionary accounts. This gives professors a financial incentive to use the library's service, and the administration can cut faculty spending on RAs. See also infra II 20 regarding the role of an associate dean for research. 
their effectiveness. Our primary area of expertise is still not included on the bar exam. Furthermore, useful measures for assessment of library collections or services continue to elude us. ${ }^{18}$ "When a dean looks at a law school budget, the biggest expenditure after faculty salaries is the library, and many must now wonder 'what are all those people doing with all that money?"' 19 Unless we change our priorities, layoffs and budget cuts will, and should, land disproportionately on the library.

I7 Of course libraries have advantages as well. They employ highly educated and creative people who, having lived through transformative change in their own profession, bring flexibility and adaptability to this difficult time in legal education. Most libraries can still cancel print subscriptions to save (potentially) hundreds of thousands of dollars, money which might be reallocated to save crucial staff positions. Another even more hopeful route is for everyone in the library to embrace services that support new institutional priorities. ${ }^{20}$

\section{What Do Deans and Professors Want from the Library?}

I8 What should the library do to maximize its value to the school? We can ask deans and professors that question directly, but we should not expect useful responses. My experience last year as the librarian on an ABA site inspection team ${ }^{21}$ confirmed earlier impressions that we gain little from general inquiries:

Librarian: Are you happy with the library?

Professor: Oh, they're absolutely wonderful!

Librarian: That's great to hear. So what are they doing that you really like?

Professor: Um, well, when I contact them they respond right away. And they get me whatever I want. They can track down anything. They're diligent, responsive ... just really great people.

Librarian: Great, well, is there anything you'd like to see the library do more or better?

Professor: Gosh, no, I can't think of anything. ... They're just terrific.

18. The ABA has moved from quantitative oversight (volume count, circulation statistics, etc.) to something almost exclusively qualitative. See Sarah Hooke Lee, Preserving Our Heritage: Protecting Law Library Core Missions Through Updated Library Quality Assessment Standards, 100 LaW LiBR. J. 9, 2008 LAw LiBR. J. 2. Chapter 6 of the ABA's Standards for Approval of Law Schools includes "effective support" (601(a)), "appropriate range and depth" of services (605), "sufficient financial resources" (601(b)), and "a competent staff, sufficient in number to provide appropriate" service (604). AM. BAR Ass'N, 2012-2013 Standards and Rules of Procedure for Approval of LaW Schools, 43-45 (2012). But what is "effective," "appropriate," and "sufficient"? What does "competence" look like?

19. Taylor Fitchett et al., Law Library Budgets in Hard Times, 103 Law Libr. J. 91, 95, 2011 LAW LiBR. J. 5, II 14.

20. "As we acquire fewer books ... we need fewer catalogers and fewer staff to process books. Does this mean that libraries should cut staff, or should we redirect current staff to other tasks? If so, how do we determine what we are not doing that we should be doing?” Id. at 96, II 16.

21. ABA site inspection teams typically include a librarian who finds facts that will help assess effective or competent service. Evidence of such service comes from discussions with professors and students (among others). "Evaluate the quality of library services and how this effectiveness is measured (student surveys, annual conversations with faculty, focus groups, etc.). Discuss any deficiencies in current service programs and/or any necessary services that are not offered." Joan Howland, Discussion Group G-Information Resources, Technology, and Facilities, in AM. BAR Ass'N, ABA Site Evaluation WorKSHOP (Nov. 14, 2009) (section II.3.h), http://apps.americanbar.org/legaled /accreditation/sitevisit/SEW\%20NOV\%2009\%20Dig\%20Agenda\%20Book.pdf. 
\9 It is a familiar dialogue: professors genuinely like the library and respect the people who work there. But a lack of criticism is not validation. Without specific alternatives, the professor has no context to judge services. ${ }^{22}$ Yet we often intuit our value to the school from such affectionate but ignorant expressions of support. Internal surveys and anecdotal evidence are not enough. ${ }^{23}$

I10 Only through a deeper understanding of the school's priorities and faculty needs can the library thrive in this new era, and everyone who works in the library is responsible for gaining that understanding. Any library staff member can be more active in the law school community, perhaps by developing relationships with individuals in other departments, or by attending colloquia and events. One might learn about major strategic objectives: for example, the school could be embracing (belatedly) Carnegie-style curricular reform, ${ }^{24}$ developing a new LL.M. or certificate program, expanding the use of technology in teaching, launching an online continuing legal education series, or seeking new sources of revenue. Small projects may emerge as well, such as meeting the needs of faculty members who want to learn about grant-funding opportunities, or assisting journal editors in revamping their web sites. Gathering intelligence of this sort can help the library to overcome the school's challenges, and it also broadens our understanding of what motivates professors.

\section{Motivation: Why Law Professors Teach, Write, and Serve}

I11 We cannot hope to understand the interests, and thus the needs, of "the faculty" as if it is a monolithic entity. Different subgroups (e.g., nontenured, clinical, legal writing) are likely to be motivated by different needs and goals. ${ }^{25}$ It is important to recognize that, like all people, individual professors mix values, priorities, and insecurities with other combustible elements. These quirks and preferences may be useful in customizing library services. ${ }^{26}$ Nevertheless, we can speak

22. But see Yirka, supra note 16, at 29-30 ("While it is more common for librarians to ask users if they like the library's services, it is uncommon for librarians to ask open-ended questions.”).

23. Of course, it can be helpful, after dreaming up new services, to gauge the faculty's interest. They (or their representatives on the library committee) can evaluate a specific proposal in relation to their own needs.

24. See generally William M. Sullivan et al., Educating LaWyers: Preparation for the Profession of LaW (2007) (Carnegie Report).

25. Some professors become less productive after they pass the tenure threshold. See Ira P. Robbins, Exploring the Concept of Post-Tenure Review in Law Schools, 9 STAN. L. \& POL'Y REV. 387, 387 (1998) (defining "deadwood" professors as "extremely underproductive or detached from their work"). On the other hand, tenured professors may be more open to blogging or other borderline scholarly activities that can be more interesting than law review articles and can reach a broader audience. See J. Robert Brown Jr., Essay, Law Faculty Blogs and Disruptive Innovation, 2 J. OF L. 525, 548-49 (2012) (arguing that blogging can enhance name reputation, increase SSRN downloads, and otherwise "rout[e] around traditional means of determining reputation"); see also Stephanie Davidson, Way Beyond Legal Research: Understanding the Research Habits of Legal Scholars, 102 LAW LIBR. J. 561, 578, 2010 LAW LiBR. J. 32, II 42 (arguing that faculty status is likely to affect research habits in terms of funding, community relationships, and time available).

26. There are many labels we can attach to law professors: "(un)productive scholars," "(dis)engaged colleagues," "(non)tenured," "tech savvy," "(future) deans," "clinicians," "professionally active," etc. Any one of these may suggest a certain package of library services. Taken to an extreme 
generally about law faculty interests based on unique and pervasive aspects of the profession.

$\mathbb{1 1 2}$ In recent years, researchers have attempted to understand faculty motivation by distinguishing between intrinsic and extrinsic factors. ${ }^{27}$ Intrinsic motivators-for example, wanting to help people or make a meaningful contribution to a field of study—suggest positive ideal ${ }^{28}$ of autonomy, mastery, and purpose..$^{29}$ These drivers are sometimes described with different terms, but the idea is the same. Douglas Ray believes that "job satisfaction comes from: knowing that you make a difference; knowing that you are appreciated; knowing that you are part of a group doing something that matters; and knowing that you can continue to learn and grow." 30 While it might be possible to derive satisfaction only from within, for many, personal satisfaction grows from academic acceptance. ${ }^{31}$

T13 Extrinsic motivators-tenure and security of position, recognition of peers, financial incentives-play a major role, perhaps more than internal factors, and perhaps even more than they did for previous generations. Whether the trend toward an incentive-based "academic capitalism" is good or bad depends on one's point of view: "[Academics] ... with a sense of personal agency or those who see financial, professional or social benefits may see it as opportunity rather than imposition." 32 On the other hand, "Faculty who become temporary scholars to achieve tenure, feeling both pressed and oppressed by the need to produce three major journal articles (published in 'top tier journals'), are less likely to experience

conclusion, the library might work with the research dean to customize services in conjunction with each professor's annual evaluation. Understanding individual faculty motivation (or more broadly, that of certain subgroups) may yield insights into new and popular library services.

27. See, e.g., Paul Blackmore \& Camille B. Kandiko, Motivation in Academic Life: A Prestige Economy, 16 Res. Post-Compulsory Educ. 399 (2011); Kenneth A. Feldman \& Michael B. Paulsen, Faculty Motivation: The Role of a Supportive Teaching Culture, 1999 NeW Directions Teaching \& LeARNIng 69; William J. Rich, Essay, Balance in Legal Education: Pervasive Principles, 60 J. Legal EduC. $122(2010)$.

28. We should not forget the sadder intrinsic motivators. Shortly after I became associate director for library services at the University of Connecticut School of Law, I attended a library management workshop in California. The facilitator asked everyone to think of the things that motivated them to do their best work. People gave honest and honorable examples like "helping others" and "doing genuinely important work." My answer was "fear of failure." Fear keeps me up late and it drives me to achieve results.

29. Daniel Pink has written that human beings are motivated by autonomy, mastery, and purpose. See Daniel Pink, Drive: The Surprising Truth About What Motivates Us 85-146 (2009). But that cannot explain faculty members who have better access to each of these motivators than most workers. Law professors have academic freedom and security of position, the opportunity to mold the next generation of lawyers, and a platform to affect important debates in their areas of expertise. If autonomy, mastery, and purpose were the only key drivers, then all professors would be content and cooperative. Sadly, that is not the case.

30. Douglas E. Ray, The Dean's Role in Building a Positive Workplace Environment, 42 U. ToL. L. REv. 657, 657 (2011).

31. See Blackmore \& Kandiko, supra note 27, at 404 ("No matter how intrinsically motivated, an academic is part of a community of colleagues, whose shared epistemologies and social practices strongly influence thinking and discourse in the field and whose approval confers high intellectual standing.").

32. Id. at 402 . 
the personal enjoyment and life satisfaction associated with a lifetime of scholarship ...."33

I14 Many longtime academics say that academia was once a happier place. Faculties were collegial and involved. They met routinely both at work and socially, and were engaged with one another's work.

It was not uncommon, in the mid-1970s to all have coffee together twice a day-10:30 am and 2:30 pm. When one person moved, almost every young professor met to help. Weekends were spent together in families. Christmas parties of whole Departments were held in rented halls with $300+$ attendees, with singing and comedy and talent shows. ${ }^{34}$

The job of the "law professor" typically included a near lifetime appointment; a flexible schedule; a generous salary; a platform to influence debates of local, regional, or national significance; and the ability to help the careers of future lawyers. Although many law professors are happy and fulfilled in their careers, ${ }^{35}$ times and perspectives have changed. The professoriate is (or has become) more competitive, status obsessed, and uncooperative. ${ }^{36}$ "Now we talk about our 'heroes' by noting that 'she was published in that journal' or 'he just received a huge research award.' These are our icons; but, is their work edifying anyone-including themselves?"37

33. Rich, supra note 27 , at 125 (arguing that "extrinsic" motivators like financial rewards are potentially destructive to both the campus community and long-term professional satisfaction). Think about library services designed with not-yet-tenured professors in mind. What do they need to get through the process? Time to write? Project management? Solid administrative support? The library ought to work with the dean for research to consider the opportunities. If we reach professors when they are new, especially in a way that has a meaningful impact on something as important as tenure, then we will have customers for life.

34. Jim Parsons \& William Frick, Why Professors Hate Their Jobs: A Critique of the Pedagogy of Academic Disengagement, 7 Culture, SOC'Y \& PraXis, no. 2, 2008, at 30, 34 n.3.

35. Indeed, a survey of Yale Law School graduates demonstrates that academics are the most likely of all graduates to be "very satisfied" with their career choice. Yale Law Sch. Career Dev. Office, What Yale Law School Graduates Do: A Summary of CDO's 5th Year Career Development Survey, Classes 1996-2000, at 1, 4-5 (2001), http://www.law.yale.edu/documents/pdf/cdo-summary_memo_96_00 .pdf (noting "very satisfied" rates of $24 \%$ for law firms, $49 \%$ for business, $60 \%$ for public service, $75 \%$ for academia, and $49 \%$ overall).

36. See, e.g., Michael A. Livingston, Why Are Law Professors So Edgy?, From Milan to Mumbai (Mar. 1, 2006), http://mikelivingston.blogspot.com/2006/03/why-are-law-professors-so-edgy.html (arguing that the profession has become "(a) very competitive; (b) primarily personal (that is, noncooperative) in nature, and (c) almost entirely devoid of objective standards that might be used to measure success or failure in the activity."); Megan McArdle, The Life of the Mind, ATLANTIC (Apr. 22, 2008), available at http://www.theatlantic.com/business/archive/2008/04/the-life-of-the-mind/3296/ ("I've never seen a group of people—including investment bankers-more obsessed with status."). See also Ilya Somin, Are Law Professors Miserable, and If So Why?, Volokh ConspiraCy (Dec. 29, 2007), http://volokh.com/2007/12/29/are-law-professors-miserable-and-if-so-why/ (“[A]chievements and failures are measured by citation rates, conference invitations, offers of visiting positions, promotion to tenure, pay increases (which at many schools are at least partly merit-based), and of course student evaluations. None of these measures are perfect. But collectively they should give most professors a reasonably good indication of their professional standing.").

37. Parsons \& Frick, supra note 34, at 35; see also id. at 42 ("[T] eaching, research and service (the holy trinity of sorts) [have become] depoliticized acts reduced to 'getting ahead.' But 'getting ahead' means 'falling behind' when the effect is to deskill or remove academics from processes of deliberation and reflection."). 
We believe some things are systemic — competition for what seem like finite research dollars; strong personal competition for salary and promotion; and an academic culture driven by less than convivial philosophical groundings-and the things that go with that [such as a personal lack of efficacy and fullness that makes us, shall we say, edgy (on edge)]. ${ }^{38}$

I15 One might accept the implication of these anecdotes, yet reasonably ask whether pining for the academy of yesterday helps us to evaluate the library services of today. One response is that it does, at least to the extent that the dean and other tenured faculty members seek a return to those happier times-in that case the library could develop ways to help in the transition. ${ }^{39}$ Indeed, we might hope that innovative support will result in more successful scholarship, which will in turn lead to a friendlier working environment. ${ }^{40}$ A second, less sentimental response is that we ought to limit our inquiry to factors that do motivate professors, and ignore those that either used to, or never did, have an effect. The quest for recognition and reputation are real enough, though not necessarily indicative of our best natures.

I16 The desire for recognition from the public, from the news media, from students, and most crucially from peers (internal and external) is a critical motivator. Faculty watch for lateral moves, appointments to national committees, publication in visible journals, invitations to speak at conferences, and mentions in the blogosphere as evidence of professional importance. ${ }^{41}$ Seen in this way, we understand why teaching may come second, and service (including governance) a distant third; after all, teaching and service are less directly associated with reputation, at least outside the building. ${ }^{42}$

I17 In my early years at William Mitchell, I attended a faculty workshop on the importance of self-promotion. Professors shared tips on using social media, submitting articles to nonlegal or interdisciplinary publications, and speaking at conferences. ${ }^{43}$ Attendees were encouraged to "squeeze the juice" out of their research and writing. Every good idea should be heard by as many people, in as many ways,

38. Id. at 34 n.3.

39. For a fascinating read, including a fourteen-step process for returning to a "successful pedagogy of engagement" in the academy, see id. at 43-45. Cf. Jayne W. Barnard, Post-Tenure Review as If It Mattered, 17 J. Contemp. Legal Issues 297, 319-22 (2008) (proposing that law schools tie faculty compensation to "performance and adherence to institutional values" such as innovation, regular production of high-quality scholarship, enthusiasm, and constructive participation in faculty governance).

40. See Mardy T. Eimers, The Role of Intrinsic Enjoyment in Motivating Faculty, THOUGHT \& Action: The NEA Higher Educ. J., Fall 1997, at 125, 131 (finding that "measures to help faculty be more successful in their scholarly endeavors may lead to the higher levels of satisfaction with the extrinsic recognition they receive from research.").

41. "The folks at lower-tier schools think they belong at top-20 schools, the folks at other top-20 schools think they belong at Harvard, and the folks at Harvard think that they deserve more recognition than the other folks at Harvard." Arnold Kling, Diminishing Returns and Life, ECONLog (Apr. 21, 2008), http://econlog.econlib.org/archives/2008/04/diminishing_ret.html.

42. On the other hand, the importance of good teaching is probably making a comeback in this law-school-bashing, reform-demanding, post-Carnegie era.

43. The blogosphere offers occasional tips on self-promotion for law professors. See, for example, Paul Secunda's series on PrawfsBlawg (http://prawfsblawg.blogs.com/prawfsblawg), including Self-Promotion \#5: Hodge Podge of Ideas (Nov. 16, 2009), http://prawfsblawg.blogs.com/prawfs blawg/2009/11/selfpromotion-5-hodge-podge-of-ideas.html. 
as possible. ${ }^{44}$ The model of writing an article, submitting it for publication, and then moving on to other projects was shunned as incomplete and outmoded. The reason, according to the presenters, was that our practical work should not be hidden; instead the community should put it to use. Thus self-promotion, once (and still, in some circles) regarded as tacky, had been reborn and swaddled in a wrapper of social good. But it also appealed to professors' desire for recognition, not to mention the law school's interest in promoting a faculty with national impact. ${ }^{45}$

I18 The workshop spawned a fascinating law school task force on enhancing the visibility of faculty work. The group took its work seriously and had the approval of both law school administration and the faculty as a whole. No surpriseits work hit the sweet spot between professorial and institutional self-interest.

I19 Understanding patrons' needs has always been central in librarianship-in reference or circulation interactions, in developing or refining services, and so on. Dipping below the surface to ascertain what motivates the law school and its faculty has major implications as we reimagine the academic law library. We know that law schools are seeking to cut expenses, that promotional efforts are valued but pushed back to professors, and that professors are increasingly motivated by external factors like recognition and reputation.

\section{Support for Production and Visibility of Faculty Scholarship}

I20 From time to time law schools post announcements of positions like "Associate Dean for Faculty Development" or "Vice Dean for Research." ${ }^{6}$ These jobs are generally designed to help professors get their work published and disseminated broadly, find speaking engagements, and increase attention for the school, among other things. ${ }^{47}$ The fact that schools have advertised for positions like this is evidence of the desire for increased scholarly productivity and visibility. ${ }^{48}$ But law schools do not need more deans; instead they need to trim administrative costs during a historic period of declining enrollments.

44. This seems an opportune moment to state that these suggestions were neither bad nor base. There were, in fact, numerous good and practical ideas shared during the meeting. Without attaching judgment, I seek to recognize and learn something real about human nature, and (eventually) suggest corresponding implications for library services.

45. Reputation is worth a combined forty percent of the U.S. News \& World Report rankings. See Theodore P. Seto, Understanding the U.S. News Law School Rankings, 60 S.M.U. L. ReV. 493, 506 (2007). Faculty members' efforts to promote their own work are doubly important in an era of fiscal austerity. Marketing and public relations groups must also focus on campus events and calls from news media, etc.

46. Common functions of a faculty development position include mentoring and assistance with professional development opportunities; oversight of grants, awards, fellowships, and development funds; development of programs on writing and teaching; assistance with curriculum planning; and maintaining a calendar of faculty development opportunities.

47. See Joseph P. Tomain \& Paul L. Caron, The Associate Dean for Faculty Research Position: Encouraging and Promoting Scholarship, 33 U. TOL. L. REV. 233, 234 (2001). At the University of Toledo College of Law, the associate dean position was created to "(1) promote excellence in scholarship and teaching; (2) facilitate and coordinate scholarly activities; and (3) publicize the scholarly activities of the faculty." Id.

48. See generally James Lindgren, Fifty Ways to Promote Scholarship, 49 J. LEGAL Educ. 126 (1999). Professor Lindgren offers terrific suggestions on creating an internal environment in which scholars can thrive. $I d$. at 127-32. He suggests that schools create research dean positions, noting that "Texas 
I21 With significant financial and public relations stress, law schools may deemphasize scholarship in favor of teaching because teaching has a more direct and obvious correlation with student outcomes and is, therefore, more responsive to critiques of legal education. Libraries can add immediate value to the school by absorbing functions related to promotion and dissemination of scholarship, including many of those held by research deans, and others that professors have been asked to accomplish on their own. ${ }^{49}$ Librarians have (or can develop) the talents necessary to take primary responsibility for faculty development.

I22 This new role is not a stretch. Even now, research deans cannot serve optimally without the cooperation and support of the library. After all, librarians conduct research, and often coordinate research assistant pools, to guarantee high-quality inputs for scholarship. ${ }^{50}$ We know that as sources of information proliferate, professors need more help in searching and filtering. ${ }^{51}$ Increasingly, it is not enough to scan for articles in one's area, run keyword searches in favorite databases, and talk to peers. Professors who are provided with better source materials have an advantage, and creative librarians hold the key.

I23 Research is the library's sphere of influence, and the scholarly cycle moves quickly from there. In between research and the finished product, professors are usually alone with their computers and their coffee, ${ }^{52}$ and then, after the article is finished, a research dean may offer advice on how to place it in an appropriate journal. But experience and anecdotal evidence suggest that many professors handle the postcompletion work alone (or with the help of an administrative assistant), leading to inconsistency, inefficiency, and error.

and Georgetown, schools that have associate deans for research or scholarship, have registered staggering increases in faculty productivity over recent years." Id. at 130.

49. See Margaret A. Schilt, Faculty Services in the 21st Century: Evolution and Innovation, 26 LEGAL REFERENCE SERVICES Q., nos. 1/2, 2007, at 187, 204 (advocating for librarians to provide faculty members "with whatever help will give them more time to spend thinking and writing, and to assist them with getting their thinking and writing to the audience they are seeking.").

50. See generally Kirk \& Rainwater, supra note 17.

51. See Schilt, supra note 49, at 195 (arguing that faculty members "are drowning in resourceswhat they need are ways to tease out of the deluge those resources that are valuable to their work").

52. On the other hand, maybe there is room for librarians to offer ongoing help. I once had a memorable conversation with a law professor, who said her research process had regressed over the years. Decades earlier she had learned the "index card method" for taking notes and organizing her thoughts. She stored batches of cards in a box, and then when she was ready to write, she would pull them out, put them in order, switch them around, and so on. These days she has Westlaw and LexisNexis printouts, bookmarks to web sites, documents she has found and downloaded, e-mails from colleagues (or herself) referencing materials in various locations, books from the library, and photocopies delivered via interlibrary loan. Now, much more than earlier in her career, she works on numerous long-term projects at once. Furthermore, she writes from home, in her office, at coffee shops, and while traveling. Version control had become a big problem because she e-mailed halfcompleted files to herself and had inconsistent access to network space from off-site. These problems were multiplied when collaborating with colleagues. She assumed that librarians had somehow solved this problem, so she asked for my advice. Sadly, I had experienced many of the same frustrations. Since then I have promoted various tools, notably Zotero (www.zotero.com) for research management. There is clearly room for library expertise at stages of the research process that had typically been considered the sole province of law professors as authors. 
I24 I propose a more streamlined process that better utilizes librarians' talents and garners more attention for faculty work. One librarian should serve as scholarly communication "czar," responsible for the school's publication and open access efforts, including SSRN, ${ }^{53}$ ExpressO, ${ }^{54}$ and the institutional repository. This librarian might reasonably emerge from either public or technical services. ${ }^{55} \mathrm{~A}$ designated point person signals the library's commitment to the endeavor and provides a contact for faculty members and vendors. ${ }^{56}$

I25 If the school does not already have an institutional repository, the library should invest in one. ${ }^{57} \mathrm{~A}$ repository houses a publicly accessible record of the school's intellectual output ${ }^{58}$ and serves as the cornerstone of its participation in the open access movement. Open access initiatives (and the repository specifically) build connections with the community (including the bench and bar), assist with fund-raising, ${ }^{59}$ expose the school's work to a national or even worldwide audience, and accomplish a social good by unlocking valuable information. ${ }^{60}$ Undertaking this repository project will have the support of faculty members because the library can promise vastly increased reach for their work, ${ }^{61}$ and support for open access

53. SSRN (www.ssrn.com) is the Social Science Research Network, an interdisciplinary scholarship repository widely embraced by law professors and valued for its download tracking statistics.

54. ExPRESSO, http://law.bepress.com/expresso/ (last visited Jan. 26, 2013). ExpressO is a manuscript submission service developed by Berkeley Electronic Press (bepress) that allows authors to send completed articles to dozens (or hundreds) of law journals at once and monitor acceptance or rejection.

55. Reference librarians might seem the obvious choice because of their preexisting relationships with professors, but this role also has great potential for catalogers or others in technical services. For one thing, as libraries cut print collections, those who had processed print materials have more time available. More important, many of the skills necessary to spearhead and maintain an open access initiative are possessed by technical services librarians: an understanding of taxonomy and controlled vocabulary, being consistent and organized, and attention to detail.

56. Anyone who has spent significant time evaluating or using institutional repositories can confirm the importance of a dedicated individual. Without one, repositories often languish. It is embarrassing to the school to present a repository, ostensibly its public archive of faculty work, to which nothing has been added for years.

57. Ideally the school will supplement the library's budget, but regardless, libraries must find the money. Digital Commons, for example, costs between $\$ 15,000$ and $\$ 20,000$ per year for hosted, supported service. See Digital Commons, http://digitalcommons.bepress.com (last visited Jan. 26, 2013). DSpace is open source, locally hosted software, which means it is cheaper, highly customizable, and more staff-time intensive. See DSPACE, http://www.dspace.org (last visited Jan. 26, 2013).

58. For a great overview of open access in the context of legal education, including considerations for implementing an institutional repository, see Carol A. Parker, Institutional Repositories and the Principle of Open Access: Changing the Way We Think About Legal Scholarship, 37 N.M. L. REv. 431 (2007).

59. See David Shulenburger, Closing Keynote at SPARC Digital Repositories Meeting (2008), http://www.arl.org/sparc/bm doc/shulen_trans.pdf ("The job of digital repositories is to ensure that the extremely valuable scholarly or creative products that have been paid for by the public or by donors are ultimately accessible to them, as well as to students, faculty and researchers everywhere.").

60. See Richard A. Danner, Applying the Access Principle in Law: The Responsibilities of the Legal Scholar, 35 INT'L J. LEGAL INFO. 355, 394 (2007) (encouraging scholars to "insist that the journals which accept their works be openly accessible or at least allow authors to post their accepted works in institutional or disciplinary open access repositories.").

61. See Parker, supra note 58, at 466 ("[O]ne need only visit the topic of download counts to find evidence that one of the driving forces behind archiving in open access repositories is increased visibility, and thus increased impact of one's work."). 
initiatives will increase as professors see the repository's effects in terms of download counts, among other benefits. ${ }^{62}$

I26 Facilitating free and open access to scholarship virtually guarantees that more people will read and cite to it. ${ }^{63}$ Important research conducted by James Donovan and Carol Watson demonstrates that "[o]pen access legal scholarship ... can expect to receive fifty-eight percent more citations than non-open access writings of similar age from the same venue." ${ }^{34}$ The effect appears to be quite durable, with older articles (including many uploaded to open access venues years after traditional publication) continuing to be found and cited at a higher rate than articles published in print alone. ${ }^{65}$ The reasons are uncertain, though easier availability of materials via Google and other search engines seems the most significant cause. ${ }^{66}$

I27 Professors may ask whether articles already on SSRN ought to have a second open access home. The issue is whether a repository will siphon away a percentage of authors' SSRN downloads, resulting in diminished ranking and status. Donovan and Watson believe that the question arises from a faulty "zero-sum" assumption; namely that readers for a particular article are a scarce resource, and adding multiple access points divides them. ${ }^{67}$ Instead, they argue that

SSRN and IRs more likely draw from different readerships, meaning that downloads recorded for the repository copy represent not diverted SSRN readers but a new audience for the content. SSRN and IRs do not fight for the same eyeballs, but instead target different populations defined by how readers find their way to the desired content. ${ }^{68}$

I28 Our law school's experience with using both SSRN and our repository, Mitchell Open Access, supports Donovan and Watson's key conclusion; namely that

62. Professors who never expressed much interest in open access report their appreciation for receiving monthly download statistics from the repository. Probably a part of it is vanity, but there are other reasons as well. Seeing a spike in downloads for an older article tells a professor that a longforgotten research interest may be worth revisiting. Professors have also been invited to submit new articles for forthcoming symposia, or to present at conferences, because of work found in the institutional repository or SSRN.

63. Dozens of studies in various fields have demonstrated the increased impact factor of open access articles. See The Effect of Open Access and Downloads ("Hits") on Citation Impact: A Bibliography of Studies, Open Citation Project, http://opcit.eprints.org/oacitation-biblio.html (last updated Dec. $5,2012)$.

64. James M. Donovan \& Carol A. Watson, Citation Advantage of Open Access Scholarship, 103 LAW LiBR. J. 553, 570, 2011 LAW LiBR. J. 35, II 50.

65. See id. at 571-72, II 56.

66. Donovan and Watson note three possible causes: the open access postulate (convenient access), the early access postulate (earlier uploading gives the author a foothold on hot topics), and the self-selection bias postulate (authors self-select their best work to post online). Id. at 570-72, III 51-56. They dispute the notion that more convenient access explains citation advantage because law professors already have access to legal periodical literature via HeinOnline, LexisNexis, and Westlaw. $I d$. at 571, II 53. Yet they do not consider the possibility that faculty research habits have changed, and that, like students, faculty have begun to utilize general search engines either before or instead of fee-based databases to find legal literature. See Davidson, supra note 25, at 572, II 25 (acknowledging our lack of knowledge about faculty research process and preferences). "Do faculty scholars use the resources that librarians expect them to use?" Id. at $\mathbb{I} 26$.

67. James M. Donovan \& Carol A. Watson, Will an Institutional Repository Hurt My SSRN Ranking? Calming the Faculty Fear, AALL SpeCTrum, Apr. 2012, at 12, 12.

68. Id. 
redundant posting dramatically increases net downloads. ${ }^{69}$ In William Mitchell's case, SSRN downloads have declined marginally since the debut of Mitchell Open Access, but net downloads have skyrocketed. ${ }^{70}$ This is the rare service with no downside; it provides broad dissemination of faculty work, predictable and enthusiastic institutional support, quantifiable and measurable success, and fixed costs (excluding staff time). ${ }^{71}$

I29 At the same time as libraries evaluate repository platforms and build support, they can improve their schools' scholarship content on SSRN by undertaking a retrospective uploading project. This process includes scanning articles from print journals in the collection (absent an author's digital copy, or an agreement with HeinOnline to reuse already digitized files) and obtaining permission from copyright holders. ${ }^{72}$ Luckily most student-edited, law-school-supported journals allow for open access reuse, or will readily grant permission. ${ }^{73}$ Naturally, libraries will also need permission from professors, but should experience few obstacles if they have institutional support and inform faculty about the project. ${ }^{74}$

I30 Completing a repository or retrospective SSRN-uploading project will build the library's credibility and help librarians understand and appreciate the breadth of the faculty's work. Other valuable steps are for the library director to serve as the school's SSRN editor (if such a position exists), ${ }^{75}$ and for both the director and the scholarly communication librarian (among others) to attend faculty colloquia. ${ }^{76}$

69. Mitchell Open Access, William Mitchell Coll. of LaW, http://open.wmitchell.edu (last visited Jan. 26, 2013).

70. See the appendix infra for a chart of download numbers.

71. Readers may see the cost as a drawback, but I view it as a beneficial reallocation of resources.

72. See Parker, supra note 58, at 468-72 (describing issues related to obtaining permission from journals that own exclusive copyright in already published works).

73. Experience shows that student-edited journals rarely deny permission (if they even respond to permission requests), but peer-reviewed journals (especially those owned by for-profit companies) rarely grant it. The approach apparently taken by some law schools of posting all materials until the copyright holder objects is simpler, but not recommended.

74. The promise of faculty visibility with expert support and no additional outlay of funds should generate institutional enthusiasm. Notify the faculty without asking for permission. Describe the library's plan and rationale, and tell them their feedback is welcome. When it comes time to upload articles, e-mail each professor with a list of the articles ready to post. Their feedback will likely focus on specific articles to add or subtract from the list, not on the initiative itself. "We are doing this, let me know if you object" is more effective than "we would like to do this, let me know if it is okay."

75. The value of having an SSRN editor is that it signals the law school administration's embrace of open access, or at least of the widest possible dissemination of faculty work. Even if library directors cannot get the title, they are well positioned to know what other professors are writing, and can serve as a conduit of information for librarians working on open access projects.

76. Ideally all librarians would attend, and participate actively in, workshops at which professors present their research. This serves the library's goals of institutional visibility and knowledge of faculty interests, and it lays the groundwork for future professor-librarian collaboration. 
\$31 Armed with knowledge of ongoing projects, ${ }^{77}$ librarians should check in with professors periodically. ${ }^{78}$ Upon completion of a full draft, ${ }^{79}$ the librarian can offer a preliminary citation check, ${ }^{80}$ designate key words, write an abstract (if necessary), post the article to SSRN, add it to the school's SSRN Research Paper Series, and submit it for inclusion in selected SSRN Subject Matter eJournals. ${ }^{81}$ Immediately thereafter, the librarian can add a link to the professor's online bibliography ${ }^{82}$ and add an entry to the database of faculty accomplishments. ${ }^{83}$

\$32 Between uploading a working paper and finalizing the manuscript for publication, the library should shift to a marketing role. Librarians can promote the work from their Twitter or other social media accounts, ${ }^{84}$ identify blogs or listservs whose authors and readers might be notified, suggest participation in internal colloquia or topical conferences (particularly those venues that will allow professors to present their work), and encourage authors to thank those upon whose work they developed their ideas. ${ }^{85}$ Librarians might also work with the alumni relations

77. The director may want to visit faculty members who have "fallen off the grid" and ask what is going on, perhaps offering to pair them with a librarian or have someone work with their research assistants, or do whatever it takes to position the library to help kick-start their research.

78. The librarian may need to be aggressive. If a response to e-mail is not received, the librarian must visit the professor's office and say, "This is what I need." The challenge is that many librarians are uncomfortable pushing professors. They are used to responding to requests, not making them, and certainly not demanding a response. This transformation from librarian-in-service to librarian with a separate, equally important task will need acceptance and support for it to succeed. Librarians may need coaching, but in the end both groups may end up with more realistic and accurate perceptions of each other-librarians will see professors as regular people, and professors will see librarians as the professionals they are, and think of them more as colleagues.

79. Professors may be reluctant to upload works in progress. They want to present their best work, which is understandable. But the library can articulate the value of staking out one's territory online and obtaining early reactions, while also beginning to accumulate downloads.

80. Michelle Cosby offers several suggestions for library service in support of publishing, including editing and citation checking. Michelle Cosby, Assisting Faculty with Publishing: How Libraries Can Assist Faculty Throughout the Publication Process, AALL SPECTRUM, Feb. 2012, at 15.

81. SSRN features hundreds of "eJournals" that include newly posted articles on topics both narrow and broad. Most pertinent to this discussion is the Legal Scholarship Network (LSN), SSRN's umbrella for law related e-journals. See Legal Scholarship Network Journal Offerings, SSRN, http:// www.ssrn.com/update/lsn/lsn_jrl.html (last visited Jan. 26, 2013), for a complete list of LSN subject matter e-journals. One example of a dedicated librarian's value is in selecting appropriate e-journalseach one has a unique subscriber list, and inclusion in nonlegal or interdisciplinary e-journals is a good way to expose a work to a wider audience.

82. In an ideal world, the library also controls faculty bibliographies online, guaranteeing consistency of inclusion and formatting.

83. Each law school should have a single, comprehensive, reliable database to track faculty scholarship and accomplishments. It can be used to generate monthly activity reports, track scholarship posted in SSRN and the institutional repository, and assist with promotional activities. It could also include media mentions, awards, presentations, congressional (and other) testimony, blogging, committee work (ABA, AALS, etc.), or other activities of particular interest to the school. The library's technology expertise, along with its interest in promoting faculty work, make it a good choice for developing and maintaining this database.

84. See Benjamin J. Keele \& Michelle Pearse, How Librarians Can Help Improve Law Journal Publishing, 104 Law Libr. J. 383, 404, 2012 LaW Libr. J. 28, I 51 (“[L]ibrarians are well situated to know which Web 2.0 channels are ideal venues for marketing journals or individual articles.").

85. I credit my colleague, Professor Ted Sampsell-Jones, for this last idea. He suggests that authors send their SSRN link to people whose work they have cited (with approval). It is a form of networking, ego-stroking, and useful self-promotion to say, in essence, "I wanted you to see my new article because your work really got me thinking." 
department to promote the work to the author's former students, or to graduates who practice in a related area. After publication, librarians can set up Google Alerts (or similar services) to monitor reaction. ${ }^{86}$

\$33 Having "workshopped" the article and incorporated feedback, the professor should send the completed manuscript to his assigned library contact. ${ }^{87}$ The library, which, in many cases, budgets and pays for an institutional ExpressO account, also should handle the manuscript submission process. ${ }^{88}$ During this stage the library can (1) ensure all formatting and similar requirements are met; ${ }^{89}$ (2) utilize the preferred submission method for specific journals (e.g., Scholastica ${ }^{90}$ instead of ExpressO); (3) suggest the best time of year for submission; ${ }^{11}$ (4) help authors balance offers of publication for the greatest impact and fit; ${ }^{22}$ and

86. Alerts, Google, http://www.google.com/alerts (last visited Jan. 26, 2013). Many professors do not know how to track mentions of their name in a systematic way. Most people Google themselves at least occasionally, but far fewer get alerts every time their name pops up. See Anson Alexander, Googling Yourself and Why It Is Important, AnsonAlex.COM (July 30, 2012), http://ansonalex.com /technology/googling-yourself-and-why-it-is-important-infographic/.

87. Note that librarians must have enough support so that they need not handle tasks that can be accomplished by paraprofessionals, student workers, or the library's administrative assistant (if it has one).

88. Bepress currently offers two institutional memberships for ExpressO: Open Account Plan (\$2.20 per submission, with billing for actual use); and Complete Prepaid Plan (\$2200 per year for unlimited use). Pricing, ExPRESSO, http://law.bepress.com/expresso/index.html\#index_pricing (last visited Jan. 26, 2013).

89. See Allen Rostron \& Nancy Levit, Information for Submitting Articles to Law Reviews \& Journals, http://ssrn.com/abstract=1019029 (last revised Feb. 1, 2013).

90. SCHOLASTICA, https://scholasticahq.com (last visited Jan. 26, 2013). Scholastica is a relatively a new journal submission platform-a competitor to ExpressO. Only a small number of law journals use it so far, but of those, two highly ranked journals (California Law Review and University of Chicago Law Review) no longer accept articles through ExpressO.

Evidently ExpressO's institutional subscription, which allows submission of articles to hundreds of publications simultaneously, has swamped editorial staffs. This means that many journals, already notorious for valuing author reputation over content, can do even less analysis than before when choosing articles. The University of Chicago Law Review and the California Law Review may see Scholastica's \$5 fee as a way to limit submissions to authors who really want to publish in their journals. See Dan Filler, ExpressO Under Attack? Scholastica and the Five Dollar Submission, FACULTY LOUNGE (Aug. 6, 2012), http://www.thefacultylounge.org/2012/08/law-review-submissions-rise-of -scholastica-demise-of-expresso.html; see also James G. Milles, Redefining Open Access for the Legal Information Market, 98 LAW LiBR. J. 619, 631-32, 2006 LAW LiBR. J. 37, II 42 (noting that in other disciplines, submission to twenty or more journals "would be considered highly unethical, but it is standard practice in legal scholarship").

91. A few years back I attended a bepress presentation about the best and worst times of year to submit an article for publication. Spring is the worst time to submit an article because recently elected student board members are inexperienced and afraid to commit. June and July are better because editors have free time after exams. By August, the window of opportunity is closing because students are preparing for the new academic year. By September and October, full editorial staffs have assembled to read article submissions and choose the majority of the year's articles. Over the winter, journals look for last-minute replacements because a certain number of their authors miss deadlines.

92. See, for example, Washington \& Lee University School of Law's remarkable Law Journals: Submission and Ranking site, http://lawlib.wlu.edu/LJ (last visited Jan. 26, 2013), which allows scholars to rank general and subject-specific journals based on citations to those journals in cases, later articles, etc. 
(5) recommend license agreement modification to guarantee the school's future ability to disseminate or reuse the work..$^{93}$

\34 Upon formal publication, the library should post the finished product to the institutional repository, thus providing a complete record of the law school's scholarly output. At the same time, the draft version on SSRN should be replaced with the final article ${ }^{94}$ and the published journal citation added. Last, the library should update the citation on the professor's online bibliography and in the school's database of faculty accomplishments, and also add links to the institutional repository.

\$35 After publication, the library can continue to promote the work via social media and monitor the blogosphere for reaction. Postpublication is a good time to ask professors if they want to see a list of nonlegal publications that might publish a similar piece. If the author has reprints, the library can suggest individuals (e.g., scholars, deans, or alumni) who might like to receive copies. The library can also find a practitioner to write a short review of the work for a school publication, thereby creating a connection with a member of the bar and demonstrating the practical utility of faculty work. Finally, the library can distribute to the faculty and administration lists of recently published works (including abstracts and links), along with regular statistics that demonstrate an expanded readership. ${ }^{95}$

\section{Moving Forward with Open Access: E-book Initiatives}

\36 Professors devote themselves to a variety of writing projects, including, in rough order from most to least "scholarly," monographs, law review articles, hornbooks, practice materials, study guides, and casebooks. Blogs can fit almost anywhere on the spectrum, depending on the professor's depth of treatment.

\$37 Pursuing an open access agenda for the library logically begins with law review articles for several reasons. First, rightly or wrongly, they are the principal unit of measure for legal scholarship. Tenure and national recognition derive from the placement and impact of articles. Second, school-sponsored, student-edited law journals are usually willing to allow open access publication, meaning libraries can expect relatively few copyright obstacles. Third, professors have strong incentives (and few disincentives) to participate. With no expectation of direct financial benefit from traditional law review publication, professors lose nothing by embracing open access.

\38 Obstacles to open access publishing of other types of writing are more significant. Notably, professors who produce commercial publications like treatises, casebooks, and study guides do so in part because of potential royalties. Consequently,

93. Among many useful and highly recommended resources is the Scholar's Copyright Addendum Engine, SCIENCE COMMONS, http://scholars.sciencecommons.org (last visited Jan. 26, 2013).

94. The URL stays the same to ensure uninterrupted download tracking for the piece.

95. See Lindgren, supra note 48, at 131 ("Distribution in house lets faculty members know what has been published, reminds them of what they ought to be doing, and promotes interaction and positive feedback."). 
schools must implement open access publishing in a way that counteracts any financial disincentives.

I39 Though an appropriate place to start, in certain respects articles actually offer less open access benefit than other types of scholarship. This is because the primary audience for most law review articles is other law professors, one of the few demographics that, by virtue of institutional subscriptions to LexisNexis, Westlaw, and HeinOnline, does not need open access. ${ }^{96}$ Other groups, notably students and practitioners, would most benefit from free legal content, and the remainder of this article focuses on opportunities to serve those groups.

\section{Practice Guides and Treatises}

I40 Chief Justice John Roberts Jr. made headlines in 2011 when he accused law professors of writing on topics irrelevant to the bench and bar:

Pick up a copy of any law review that you see, and the first article is likely to be ... the influence of Immanuel Kant on evidentiary approaches in eighteenth-century Bulgaria, or something, which I'm sure was of great interest to the academic that wrote it, but isn't of much help to the bar. ${ }^{97}$

Probably the comment was an attempt at humor and not a careful critique; after all, many law review articles are genuinely useful to attorneys and are cited by courts. But law review articles, like their authors, can be disconnected from practice. They are valued by academics (and sometimes policy makers) for their prescriptive nature; professors spot a problem and propose a solution. ${ }^{98}$ Practicing lawyers prefer practical tips and guidance on how to handle certain scenarios.

I41 Law schools that increasingly embrace skills training should now embrace practical writing, but instead they continue to glorify articles that typically only generate citations by other academics in later law reviews. ${ }^{99}$ Law professors who write practical treatises or blogs do so with the knowledge that their work will be marginalized by their colleagues. ${ }^{100}$

96. See Donovan \& Watson, supra note 64 , at 571 , II 53 (“[L]aw faculty already have as much access to the periodical literature as they can use.").

97. John G. Roberts Jr., Annual Fourth Circuit Court of Appeals Conference, C-Span (June 25, 2011), http://www.c-span.org/Events/Annual-Fourth-Circuit-Court-of-Appeals-Conference /10737422476-1/ (quote at 30:39). The comments provoked considerable response from academics and commentators. See, e.g., Richard Brust, The High Bench vs. the Ivory Tower, ABA J., Feb. 2012, at 50 .

98. Of course, law review articles might not be an adequate vehicle even for academics to talk to one another. "The wider question is whether the law review model of content-with its long lead time to publication, editing by students, and format that's resistant to after-publication editingyields enough scholarly gems to deserve surviving in its present form even online." Walter Olson, Abolish the Law Reviews!, ATLANTIC (July 5, 2012, 12:40 P.M.), http://www.theatlantic.com/national /archive/2012/07/abolish-the-law-reviews/259389/.

99. See, e.g., Brian Leiter, Top 70 Faculties in Scholarly Impact, 2007-2011, BRIAN LeITER's LAW SCH. RANKINGS (July 2012), http://www.leiterrankings.com/new/2012_scholarlyimpact.shtml. A potentially useful exercise is to imagine other metrics for evaluating the importance of law review articles (e.g., citation in briefs submitted to trial and appellate courts and citation by judges).

100. See Milles, supra note 90, at 632-33, II 48 ("Once the chief purpose of legal scholarship, and nostalgically recalled by the bench and bar, this is ... generally viewed by legal academics as a lower function-a pro bono service, [and] not real, significant scholarship."). 
I42 Librarians can help improve the low esteem in which practical legal writing is held by educating their communities about the need for increased competition in publications geared toward practitioners.

$[T]$ o the extent that law librarians and their professional associations devote resources to promoting open access legal scholarship, they are not only failing to address, but in fact are diverting resources from, the real problem: the soaring costs of nonscholarly, commercially published, practitioner-oriented legal publications. ${ }^{101}$

Librarians can remind professors and administrators, for example, that corporate publishers no longer have a stranglehold on the means of publication, nor do they add many unique editorial advantages. Librarians should call attention to the high cost of legal publications, which many practitioners (and law libraries) cannot afford.

I43 Practice guides ${ }^{102}$ have significant open access potential. Although they are written for attorneys, many practitioners lack meaningful access to them. In general, practice guides (including deskbooks and manuals) are available either through their publishers' platforms (e.g., Westlaw, LexisNexis, Intelliconnect) or, decreasingly, in print formats, which can be found at academic, state, or county law libraries. Large firms may purchase relevant titles, but lawyers in small firms or solo practitioners face a significant disadvantage because of the cost of these materials.

I44 One solution to this problem is for law schools to invest in student-edited practice guides instead of the traditional student-edited law review. It would engage faculty advisors in a worthwhile endeavor, give students a better educational experience (i.e., creating a substantive overview of a legal topic), ${ }^{103}$ and make a huge impact on practitioners. Students could write the work in consultation with faculty, alumni, or other practitioner experts, and keep it up-to-date. A blog connected to the guide could note recent cases and encourage discussion. ${ }^{104}$

I45 Another, (perhaps) less radical option is for one or more professors to write a treatise, but publish it for free online instead of through a traditional publisher. The issue here is that faculty members may be reluctant to embrace self-publishing if they cannot profit from the endeavor, even though relatively few treatise authors earn significant income from their work. ${ }^{105}$ Further complicating the matter is the

101. Id. at 631 , II 37.

102. These are sometimes referred to as practice materials, or lumped in with treatises. See, e.g., Steven M. Barkan et al., Fundamentals of Legal Research 72 (9th ed. 2009) (“[P]racticeoriented books usually furnish analyses of the law, practical guidance, forms, checklists, and other time-saving aids.”); Morris L. COHEN ET AL., How to Find the LAW 407 (9th ed. 1989) (“[T] he most widely used of this type are the procedural manuals issued commercially for particular jurisdictions.").

103. See Milles, supra note 90, at 633, II 51 (arguing that students engaged in editing law journals are not learning the right skills: "Journal students learn meaningless citation-checking skills and bad editing habits, but demonstrate an aptitude for tedious detail and a willingness to work hard. The trade-off is that they skip classes to produce the journal.").

104. See id. at 635 , II 59 (stating that law schools, "using readily available distribution technologies such as RSS, blogs, wikis, and other collaborative authoring tools, could easily compete with the commercial publishers of many ... legal newsletters and loose-leaf services").

105. See Eugene Volokh, The Future of Books Related to the Law?, 108 Mich. L. Rev. 823, 837 (2010) (noting that for "most law professors, the income from academic books is a small fraction of our salaries"). Volokh argues that most law professors would trade money for increased readership, but he does so not in support of open access, but in order to cut publishers out of the process, thereby increasing profits for authors. Id. at 837-38. 
allure of a professionally printed and bound finished product. ${ }^{106}$ For many professors, even though traditional publishers no longer offer many editorial services, ${ }^{107}$ holding a book and including its citation on their curriculum vitae outweigh the open access promise of enhanced readership. Of course, we should not judge faculty too harshly for feeling this way. For hundreds of years, academics have associated books with permanence, accuracy, and authenticity. The book is the physical manifestation and reminder of one's impact as a scholar. Unlike open access articles, which often go online in conjunction with a publication that is recognizable and rooted in print, an open access book has no tie to a publisher with an imprimatur of quality. The psychology is evolving, but in 2013 it remains fairly entrenched.

I46 Librarians can help speed these changes in a couple of ways. First, they should embrace open access for their own books and demonstrate the reputational benefits of enhanced readership. Most legal research books are published in print. If librarians cannot embrace open access in their own work, they will not convince others to do so; indeed, the effort might seem hypocritical. Second, librarians can recommend that their schools adopt incentives for professors to devote time to writing electronic treatises or similar projects. For example, schools can designate stipends, bonuses, or course load reductions for faculty members who pursue projects of this type. Third, librarians can continue to promote the concept with faculty allies, with the goal of finding pioneers willing to pilot the effort.

\section{Casebooks}

I47 An even better hope for a speedy transition to open access publishing is casebooks. ${ }^{108}$ Partly this is because authoring a casebook is a less desirable credential than other types of scholarship; indeed, academics may not even consider casebooks scholarship at all. ${ }^{109}$ This being the case, professors may be open to innovations in format. And again, only one professor (or a small group) is necessary to pilot an effort; unlike the institutional repository scenario, the library need not build faculty consensus or obtain administrative support to create an open access casebook. The pitch is compelling: lower costs for students, increased name recognition for both the author and the law school, customizability of content, and robust support from the library. ${ }^{110}$

106. "Publishers' selection of a book is a signal (though a necessarily imperfect one) of the book's passing at least some threshold of quality." Id. at 839.

107. See id. at 839 (noting that "many publishers don't provide much substantive editing"). One example is that authors typically now must create indexes for their own books.

108. See Matthew Bodie, The Future of the Casebook: An Argument for an Open-Source Approach, 57 J. LEgAL EdUC. 10 (2007) (evaluating technology to support electronic casebooks). The same applies to statutory supplements, for each of which students spend upward of $\$ 50$. See C. Steven Bradford \& Mark Hautzinger, Digital Statutory Supplements for Legal Education: A Cheaper, Better Way, 59 J. Legal EduC. 515 (2010).

109. Volokh, supra note 105 , at 845 ("Textbook writing is generally less valued as intellectual activity than is writing original scholarship; less valued by tenure, promotion and lateral hiring committees, less valued by colleagues, and less valued by the scholar-authors themselves.").

110. See Bodie, supra note 108, at 14 ("Because their notion of the proper course materials is likely not to match perfectly with that of the authors, most professors feel the need to 'edit' the casebook by leaving out some materials and adding others. The syllabus must carefully indicate 
I48 In 2001, Aspen published Erwin Chemerinsky's constitutional law casebook $^{111}$ with a list price of $\$ 91 .{ }^{112}$ When the second edition was released in 2005, the price jumped to $\$ 132$, a forty-five percent increase. ${ }^{113}$ The third edition, published in 2009, has a current list price of $\$ 214$, sixty-two percent more than its predecessor and well over double the original price. ${ }^{114}$ With all the major publishers implementing similar increases, it is fair to describe this as a shocking and unjustified money grab. ${ }^{115}$ Worse still, the legal academy is complicit by supplying the authors and perpetuating the market.

I49 The presence of original content or significant editorial enhancement might justify some of the cost, but sadly there is little of either. Casebooks are filled primarily with appellate decisions. These are no doubt carefully selected and edited, but the main content is obtained from bona fide government information available in the public domain. ${ }^{116}$ Also included are brief introductory narratives and questions for class discussion. ${ }^{117}$

I50 By migrating to open access casebooks, law schools could save students more than $\$ 1000$ per year. ${ }^{118}$ Helping students minimize their debt upon graduation is a worthy goal by itself, but embracing open access to course materials offers public relations benefits as well. Alumni will approve, as will prospective law students. Furthermore, law students at other schools would pressure their professors to adopt them, and those professors would comply as long as the quality was comparable. For schools that produce free, high-quality casebooks, there is a tremendous opportunity to attract attention as a leader in electronic publishing. It also

which cases, notes, or other materials are to be read, and which are to be skipped."); David M. Skover, Electrified Law: A Brief Introduction to the Workshop on the Future of the Legal Course Book, 33 SEATTLE U. L. REv. 287, 288 (2010) (reporting that "[a] typical first year law student ... could spend [up to] $\$ 1,000$ for the casebooks alone (sans supplements, secondary materials, outlines, etc.); will haul around weighty books that, all combined, tip the scales at almost $28 \mathrm{lbs}$; and will confront the specter of over 8,700 pages" of reading in print).

111. ERWin Chemerinsky, Constitutional LaW (2001).

112. Constitutional Law: Cases and Materials with Book, BookFINDER4U, http://www.bookfinder4u .com/IsbnSearch.aspx?isbn=0735520615 (last visited Jan. 26, 2013).

113. Constitutional Law, BOOKFINDER4U, http://www.bookfinder4u.com/IsbnSearch.aspx?isbn $=073554946 \mathrm{X}$ (last visited Jan. 26, 2013).

114. Constitutional Law, BOOKFINDER4U, http://www.bookfinder4u.com/IsbnSearch.aspx?isbn $=073557717 \mathrm{X}$ (last visited Jan. 26, 2013). Amazon.com sells the current edition for $\$ 177$, a 17\% discount off the list price. Constitutional Law, AMAZON.COM, http://amzn.com/073557717X (last visited Jan. 26, 2013).

115. See Natsuko Hayashi Nicholls, Univ. of Mich. Library, The Investigation into the Rising Costs of TeXtвOOKS 4 (2010), available at http://hdl.handle.net/2027.42/78553 (“[B]etween December of 1986 and December of 2004, textbook prices have increased at twice the rate of inflation, increasing by 186 percent"). Id. at 5 .

116. But see John Mayer, Rip, Mix, Learn: From Case Law to Casebooks, VoxPopuLII (May 25, 2011), http://blog.law.cornell.edu/voxpop/tag/elangdell/ (noting the problem that arises when public domain case law is only available via a subscription database).

117. Some newer casebooks have evolved from the established model and incorporate items such as learning objectives and study-aid-type materials.

118. See Coll. Bd. Advocacy \& Policy Ctr., Trends in College Pricing 2012, at 11 fig.1 (2012), available at http://trends.collegeboard.org/sites/default/files/college-pricing-2012-full -report_0.pdf (finding that four-year public college students pay $\$ 1200$ per year for books and supplies, on average). 
provides a positive message for law school administrators who desperately want to change the narrative about legal education.

I51 The Center for Computer-Assisted Legal Instruction (CALI) has been a leader in encouraging law schools and professors to revamp the casebook publication paradigm. The eLangdell initiative, which launched in late 2010, encourages professors to post textbooks with a creative commons license on CALI's platform. ${ }^{119}$ CALI's executive director, John Mayer, has since proposed an ambitious project whereby law schools would share the work of creating one hundred open access casebooks over three years. ${ }^{120}$ Under the plan,

Every law school puts forth a Fellow who will participate in a team of faculty to write a casebook in a substantive area of law over 12 months. The law school gives the Fellow leave from teaching a course or an institutional stipend for writing the book. The details are to be worked out between the school and the Fellow. ${ }^{121}$

I52 Underlying Mayer's proposal is the notion that creating open access casebooks (and achieving the critical mass necessary to upend traditional casebook publication) requires joint action by law schools. And he trusts schools to move forward based on our collective interest in lowering costs for students. Professor Orin Kerr, writing for the Volokh Conspiracy (a law professor blog), believes Mayer's plan will not work. "Specifically, it assumes that schools have an incentive to pay extra money or take professors out of the classroom so they can write casebooks, and that professors have strong nonmonetary incentives to write and update them instead of doing other things." 122

I53 I would argue that both objections can be addressed by replacing "fellow" with "librarian." For one thing, fellows cost additional money, and law schools already have librarians. A designated librarian could leverage existing faculty relationships, audit the target class to better understand how that professor might edit selected cases, find other appropriate source material, clear copyright as necessary, coordinate with administrative assistants, assign tasks to student workers and library research assistants, and outline a teacher's guide to accompany the text. Although it would mean changing priorities and making a commitment within the library, there is little reason to believe it cannot work.

119. The eLangdell Bookstore, CALI, http://elangdell.cali.org (last visited Jan. 26, 2013). The license allows for noncommercial reuse, with attribution. See About eLangdell Permissions \& Creative Commons, CALI, http://elangdell.cali.org/content/about-elangdell-permissions-creative-commons (last visited Jan. 26, 2013). "Please steal our books, as long as you're not doing so to make money off them. Seriously. Redistribute them through other free channels, repurpose them, edit them. And while we'd absolutely love to hear what you're doing with our content, you don't need to ask permission. Just give us credit." Id.

120. John Mayer, How Law Schools Could Save Students $\$ 150$ Million (Updated), CALI SPOTLight Blog (July 18, 2012), http://spotlight.cali.org/2012/07/18/how-law-schools-could-save -students-150-million/.

121. $I d$.

122. Orin Kerr, Free Law School Casebooks for Everyone? (And See Update), VolOKH CONSPIRACY (July 18, 2012), http://www.volokh.com/2012/07/18/free-law-school-casebooks-for -everyone/. 


\section{Conclusion}

I54 Librarians must understand the context within which they operate, and absorbing that context, they must refine their thinking. Instead of defending current operations, rewriting elevator speeches, confronting deans, or otherwise rearticulating their value, they must radically rethink their services, collections, and facilities in light of the law school's priorities. They must demonstrate their awareness and creativity by presenting ideas that benefit the school, even if that means reductions in service or reliance on digital collections.

\$55 This article suggests a new set of filters through which to evaluate law library services, in particular those that support faculty scholarship. Librarians should consider how their schools' strategies must change in the face of increasing competition for students, extensive public critiques of legal education in the mainstream media, and downward pressure on tuition. A library whose suite of services is designed primarily to facilitate and teach legal research will be challenged to persuade law school administrators and deans of its importance relative to other departments and roles, and is likely to face large resource cuts in the coming years.

I56 At the same time, librarians must recognize and understand the factors that motivate today's law professors. We know that professors value (and are increasingly rewarded for) journal placement, download count, media mentions, invitations to speak at events and conferences, and citation by judges and academics, among other quantifiable evidence of professional reputation. Desire for personal recognition might not foster a more collegial atmosphere, but it helps explain the popularity of library services that result in positive attention.

I57 Pitching open access initiatives as marketing for the self-interested professor may feel unsavory to librarians, but there are numerous advantages, including real collaboration with professors on issues of personal and professional consequence, development of and recognition for expertise in "trending" areas like social media and web development, and competition with the legal publishers (whose pricing policies have so damaged law libraries).

I58 Retrospectively uploading faculty scholarship, revamping the process for the submission and uploading of new articles, advising the faculty on selfpromotion, and undertaking simple marketing efforts all build a solid foundation of expertise and credibility. That foundation will support new open access initiatives because, having experienced the benefits of its past projects, professors and administrators will endorse the library's new directions.

I59 Another foundational element also plays a role: successful open access initiatives can produce cultural change within the institution-change that lays the groundwork for reconnection with the school's mission. The change in question is ensuring that all scholarship is posted for the world to use. Professors will become accustomed to seeing new work online as a matter of course. Over time, the core values of open access (e.g., facilitating broader access to valuable information) may replace self-interest as a rationale. Recall that earlier in the process few cared about providing access to information-their interests began and ended with promotion and download counts. Eventually the extrinsic motivators and the rewards of selfinterest will share space with the feeling of having done something good for its own sake. 


\section{Appendix}

Faculty Scholarship on SSRN and Mitchell Open Access

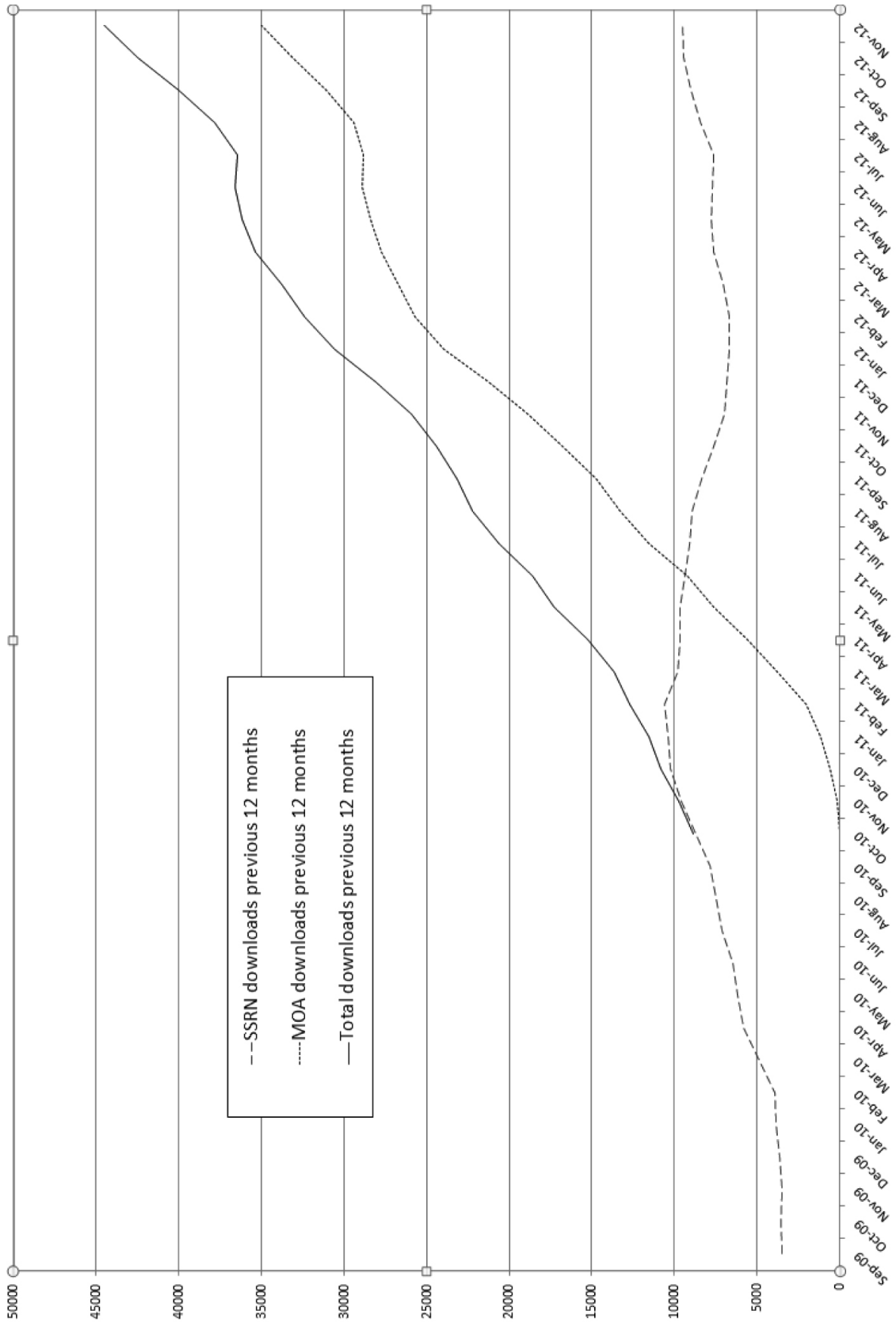

